JPDN ISSN 2579-6461 (Online) ISSN 2460-6324 (Print)

Jurnal Pendidikan Dasar Nusantara

Volume 6 | Nomor 1 | Juli 2020|

DOI: https://doi.org/10.29407/jpdn.v6i1.14523

\title{
UPAYA PENINGKATAN KEMAMPUAN BERPIKIR KREATIF MAHASISWA DENGAN PEMBELAJARAAN KOOPERATIF BERBASIS ANDROID
}

\author{
Anggun Winata ${ }^{1}$, Sri Cacik ${ }^{2}$, Heny Sulistyaningrum ${ }^{3}$ \\ anggunwinata@gmail.com ${ }^{1}$, sricacik.mpd@gmail.com ${ }^{2}$, \\ henysulistyaningrum.65@gmail.com ${ }^{3}$ \\ PGSD, FKIP, Universitas PGRI Tuban ${ }^{1,2,3}$
}

\begin{abstract}
Abstrak: $21^{\text {st }}$ century skills meliputi berpikir kritis, kreatif, kolaboratif dan komunikatif. $21^{\text {st }}$ century skills awal masih menunjukkan hasil rendah. Kemampuan berpikir kreatif merupakan salah satu ketrampilan yang penting dalam kemampuan abad 21 selain kemampuan yang lain. Penelitian bertujuan untuk meningkatkan kemampuan berfikir kreatif melalui pembelajaran kooperatif berbasis android. Penelitian ini menggunakan jenis penelitian ekperimen, desain penelitian preekperimen, dan tipe desain one group pretest postest. Analisis data hasil penelitian yang berupa lembar tes kemampuan berpikir kreatif menggunakan indikator (1) Kefasihan (fluency), (2) Fleksibilitas (flexibility), dan (3) Kebaruan (novelty). Analisi data menggunakan rumus skor gain ternormalkan. Hasil penelitian disimpulkan bahwa (1) hasil pretest indikator kefasihan, fleksibelitas, dan kebaharuan berturut-turut adalah 2,85; 1.71; dan 1,04. (2) hasil posttest indikator kefasihan, fleksibelitas, dan kebaharuan berturut-turut adalah 3,14; 3,02; dan3,35. (3) Kemampuan berpikir kreatif mahasiswa dapat mengalami peningkatan pada ketiga indikator melalui pembelajaran kooperatif berbasis android. Indikator kefasihan dan fleksibelitas memperoleh hasil sedang dengan hasil secara berturut-turut yaitu 0,50 dan 0,54 . Indikator kebaharuan memberikan hasil tertinggi yaitu 0,78 .
\end{abstract}

Kata kunci: berpikir kreatif, kooperatif, android.

\section{EFFORTS TO IMPROVE CREATIVE THINKING ABILITY OF STUDENTS WITH ANDROID-BASED COOPERATIVE LEARNING}

Abstract: 21 st century skills include critical thinking, creative, collaborative and communicative. Early 21 st century skills still show low results. The ability to think creatively is one of the important skills in 21 st century abilities in addition to other 
Winata, Cacik. Sulistyaningrum, Upaya Peningkatan Kemampuan ...

abilities. The research aims to improve the ability to think creatively through Androidbased cooperative learning. This study uses an experimental research type, a preexperimental research design, and a one group pretest posttest design type. Analysis of research data in the form of creative thinking ability test sheets using indicators (1) Fluency, (2) Flexibility, and (3) Novelty (novelty). Data analysis uses the normalized gain score formula. The results of the study concluded that (1) the results of the pretest indicators of fluency, flexibility, and novelty were $2.85 ; 1.71$; and 1.04 . (2) the results of the posttest indicators of fluency, flexibility, and renewal respectively were $3.14 ; 3.02$; and 3.35. (3) Students' creative thinking skills can be improved on the three indicators through android-based cooperative learning. Indicators of fluency and flexibility obtain moderate results with successive results of 0.50 and 0.54 . The novelty indicator gives the highest result, which is 0.78 .

Keywords: creative, cooperative, android.

\section{PENDAHULUAN}

Era revolusi industri 4.0 syarat dengan manusia yang berada pada fenomena masyarakat digital dan berpengaruh pada segala bidang, tidak terkecuali dalam bidang pendidikan. Pengaruh dalam bidang pendidikan ada kaitannya pada perkembangan dalam pembelajaran serta memberikan warna pada dunia pendidikan saat ini. Perkembangkan tersebut mensyaratkan adanya tranformasi kultur guru dan pembelajar dalam pembelajaran. Pandangan progresif, menyoroti adanya perubahan karakteristik masyarakat tersebut perlu ditinjak lanjuti dengan adanya perubahan kultur guru dalam pembelajaran sehingga guru perlu mentransformasikan diri secara teknik maupun sosio-kultural (Durkheim, 1982).

Fenomena masyarakat tersebut akan berdampak pada pembelajaran yang dirancang dan kemampuan pembelajar yang diinginkan sesuai dengan keterampilan yang dibutuhkan di era revolisi industri 4.0 yang dikenal dengan $21^{\text {st }}$ century skills. $21^{\text {st }}$ century skills menurut NEA (2002), ada 18 macam yang perlu dibekalkan pada pembelajar. Namun 4 di antaranya meliputi aspek Learning and Innovation Skills-4Cs, yang terdiri dari critical thinking (berpikir kritis), communication (komunikasi), collaboration (kolaborasi/kerjasama), dan creativity (kreatifitas). 


\section{Winata, Cacik. Sulistyaningrum, Upaya Peningkatan Kemampuan ...}

Kemampuan berpikir kreatif merupakan salah satu ketrampilan yang penting dalam kemampuan abad 21 selain kemampuan yang lain seperti berpikir kritis, kolaboratif dan komunikatif. Kemampuan berpikir kreatif dibutuhkan dalam menemukan inovasi-inovasi baru dalam kehidupan manusia. Oleh karena itu, kemampuan berikir kreatif penting dalam mempersiapkan pembelajar dalam menghadapai era revolusi industri 4.0. Melalui kemampuan berpikir kreatif dapat menciptakan ide-ide baru pembelajar berdasarkan pengetahuan yang telah dimilikinya untuk digunakan dalam memberikan solusi permasalahan dari sudut pandang yang berbeda.

Berdasarkan hasil penelitian Sulistyaningrum dkk (2019) dalam menganalisis $21^{\text {st }}$ century skills mahasiswa, menunjukkan bahwa kemampuan rata-rata untuk berpikir kritis mahasiswa menunjukkan hasil rata-rata kurang dari 30\%, kemampuan komunikatif kurang dari 50\%, kemapuan kolaboratif dan berpikir kreatif kurang dari 45\%. Hasil tersebut menunjukkan bahwa $21^{\text {st }}$ century skills mahasiswa masih sangat rendah dan perlu adanya peningkatan. Pada artikel ini, dibahas upaya peningkatan kemampuan berfikir kreatif karena kemampuan ini sangat penting karena erat hubungannya dengan kompetensi lainnya. Menurut Sultoni

\& Agoestanto (2016), kemampuan berpikir kreatif tergolong kompetensi tingkat tinggi (high order competencies) dan dapat dipandang sebagai kelanjutan dari kompetensi dasar (basic skills). Selain itu, urgensi kemampuan berpikir kreatif juga sudah lama tertuang dalam peraturan pemerintah no. 19 tahun 2005 tentang Standar Nasional Pendidikan Pasal 19 ayat 1 yang menyatakan bahwa proses pembelajaran pada satuan pendidikan diselenggarakan secara interaktif, inspiratif, menyenangkan, menantang, dan memotivasi peserta didik untuk berpartisipasi aktif, serta memberikan ruang yang cukup bagi prakarsa, kreativitas dan kemandirian sesuai dengan bakat, minat dan perkembangan fisik serta psikologis peserta didik.

Selain kemampuan berpikir kreatif berhubungan dengan kompetensi lain, hasil lebih lanjut dari penelitian (Sulistyaningrum dkk, 2019) tentang kemampuan awal terkait kemampuan berpikir kreatif mahasiswa dalam kemampuan berpikir kreatif menunjukkan hasil yang rendah terlihat bahwa (1) hasil kefasihan mahsiswa yang masih rendah ditandai dengan kurang mampunya mahasiswa dalam menjawab dan memberikan ide beragam, (2) fleksibilitas masih rendah terlihat dari pemahaman 
Winata, Cacik. Sulistyaningrum, Upaya Peningkatan Kemampuan ...

permasalahan dan solusi dalam memperkirakan secara otomatis rencana penyelesaian masalah, dan selanjutnya mahasiswa belum dapat melaksanakan rencana tersebut serta melihat kembali jika terjadi hambatan dalam memperoleh solusi, (3) kebaharuan mahasiswa masih belum dapat menyelesaikan permasalahan dan cenderung didasarkan pada pengalaman dan sebagian besar mahasiswa tidak mengubungkan kebaharuan dengan kemajuan teknologi sehingga dibutuhkan pembelajaran berbasis teknologi untuk meningkatkan kreatifitas dengan menyesuaikan kondisi sekarang.

Kemampuan berpikir kreatif merupakan proses berpikir untuk mengungkapkan hubungan-hubungan baru seperti melihat sesuatu dari sudut pandang baru, serta membentuk kombinasi baru dari dua konsep atau lebih yang sudah dikuasai sebelumnya (Suryadi dan Herman, 2008). Sejalan dengan itu, kemampuan berpikir kreatif (Coughlan, 2007) juga dapat berupa imajinasi dari individu dalam memecahkan masalah. Ada empat karakteristik berpikir kreatif, sebagai sebuah proses yang melibatkan unsur-unsur: (1) kelancaran (fluency), (2) keluwesan (flexibility), (3) keaslian (originality), dan (4) kemampuan elaborasi (elaboration) (Kim, 2006; Mahmudi, 2011; dan Siswono, 2006). Selain keempat karakteristik tersebut, indikator menganalisis kreativitas dijelaskan oleh Silver (dalam Siswono, 2008) sebagai berikut: (1) Kefasihan (fluency), yaitu kemampuan dalam menyelesaikan masalah dengan bermacam-macam solusi dan jawaban; (2) Fleksibilitas (flexibility), yaitu kemampuan dalam menyelesaikan atau menyatakan suatu cara kemudian melanjutkan dengan cara lain dan pembelajar dapat mendiskusikan berbagai metode penyelesaian; (3) Kebaruan (novelty), kemampuan dalam menyelesaikan masalah dengan jawaban yang tidak biasa dilakukan oleh pembelajar pada tahap perkembangan pembelajar atau tingkat pengetahuannya.

Pendekatan yang dapat menjadi alternatif dalam peningkatan berpikir kreatif dalam proses pembelajaran yaitu dengan menggunakan pendekatan konstruktivisme (Azhari \& Somakin, 2013). Kemampuan berpikir kreatif dapat dikaitkan dengan pendekatan konstruktivisme pada pembelajaran dengan cara pembelajar dapat mengkonstruksikan pengetahuannya yang terdahulu sehingga dapat memberi makna pada pengetahuan yang baru diperoleh Muchlis (2007). Melalu pendekatan tersebut maka pembelajar dapat terbiasa dalam memecahkan masalah, dan menemukan sesuatu yang berguna bagi maupun mengembangkan ide-ide yang ada dirinya sesuai dengan 
Winata, Cacik. Sulistyaningrum, Upaya Peningkatan Kemampuan ...

konsep kemampuan berpikir kreatif. Pembelajar seharusnya diberi kesempatan dalam mengintegrasikan dan menggabungkan informasi yang diperolehnya melalui sumbersumber yang berbeda, menciptakan kategori yang baru, serta kerangka dan modelmodel yang baru.

Saat ini telah banyak model pembelajaran yang dapat melibatkan secara aktif pembelajar dalam membangun pemahaman konsep serta penerapannya dalam kehidupan nyata. Salah satu alternatif solusi yang dikembangkan untuk mengatasi permasalahan di atas yaitu melalui pembelajaran kooperatif. Hal ini sejalan dengan hasil penelitian Florentina \& Leonard (2017) serta Heryati (2019) memberikan hasil bahawa menggunakan model pembelajaran kooperatif dapat meningkatkan kemampuan berpikir kreatif siswa. Pembelajaran kooperatif disini mensyaratkan pembelajar untuk dapat belajar dalam suatu kelompok yang terdiri dari beberapa orang untuk berinteraksi satu sama lain menyampaikan pendapat masing-masing.

Pengoptimalan proses pembelajaran selain melalui perencanaan dengan menggunakan model pembelajaran dengan pendekatan pembelajaran tertentu dapat dilakukan dengan pendayagunaan sumber belajar dan media pembelajaran. Saat ini sumber belajar yang sering dimanfaatkan karena kemudahan dalam mengakses yaitu sumber belajar berbasis online. Media pembelajaran yang digunakan dalam pembelajaran juga mulai berdeser kea rah digital dengan memanfaatkan aplikasi android. Penelitian pengembangan aplikasi android juga pernah dilakukan oleh Mardiana, (2017). Pada penelitian tersebut memberikan hasil bahwa melalui penggunaan aplikasi android sangat efektif dalam meningkatkan minat, hasil belajar siswa, dan keterampilan berpikir siswa yang meliputi berfikir kritis dan kreatif. Sejalan dengan itu, Sykes (2014) menyebutkan bahwa kelas yang dilengkapi dengan piranti dan teknologi yang tepat dan memfasilitasi kebutuhan pengetahuan yang semakin berkembang merupakan ciri dari pendidikan yang cerdas. Pemanfaatan teknologi dalam pembelajaran berbasis android menjadi salah satu alternatif pembelajaran yang sesuai dengan era perkembangan teknologi saat ini dalam menghadapai era revolusi industri 4.0.

Penelitian ini bertujuan untuk meningkatkan kemampuan berpikir kreatif melalui pembelajaran kooperatif berbasis android. 
Winata, Cacik. Sulistyaningrum, Upaya Peningkatan Kemampuan ...

METODE

Penelitian menggunakan jenis penelitian ekperimen dengan desain penelitian yaitu pre-ekperimen. Menurut Sugion (2010) bahwa penelitian pre-ekperimen hasilnya merupakan variable independen bukan semata-mata dipengaruhi oleh variable independen. Hal ini disebabkan karena tidak adanya variable kontrol dan sampel tidak dipilih secara random. Tipe desain penelitian yang digunakan adalah one group pretest postest. Pada penelitian ini, sampel diberikan pretest terlebih dahulu dan diakhir pembelajaran sampel diberikan postest. Tipe desain penelitian ini dipilih dengan tujuan untuk mengetahui upaya peningkatan kemampuan berpikir kreatif dengan menggunakan pembelajaran kooperatif berbasis android. Tipe desain penelitian one group pretest postest dapat dilihat pada Tabel 1.

\section{Tabel 1. Tipe desain penelitian one group pretest postest}

Keterangan:

\begin{tabular}{|c|c|c|}
\hline Pretest & Treatment & Postest \\
\hline $\mathrm{O}_{1}$ & $\mathrm{X}$ & $\mathrm{O}_{2}$ \\
\hline
\end{tabular}

$\mathrm{O}_{1}$ : Tes awal (pretest) sebelum dilakukan perlakuan

$\mathrm{O}_{2}$ : Tes akhir (Postest) setelah dilakukan perlakuan

$\mathrm{X}$ : Perlakukan dengan pembelajaran kooperatif berbasis android

Penelitian ini dilaksanakan di Prodi PGSD UNIROW TP 2019/2020 pada semester ganjil, dengan subjek mahasiswa PGSD Kelas C yang berjumlah 47 yang terdiri dari 40 laki-laki dan 7 perempuan. Materi yang diajarakan dalam penelitian adalah pengukuran. Instrumen yang digunakan dalam penelitian adalah silabus, RPP, buku ajar (e-book), LKM, tes kemampuan berpikir kreatif. Sebelum digunakan sebagai instrumen penelitian, semua instrumen tersebut telah diverifikasi dan divalidasi oleh validator. Teknik pengumpulan data menggunakan lembar tes kemampuan berpikir kreatif. Tujuan penelitian ini adalah upaya peningkatan kemampuan berpikir kreatif mahasiswa PGSD pada matakuliah konsep IPA setelah diterapkan pembelajaran kooperatif berbasis android. Pembelajaran kooperatif 
Winata, Cacik. Sulistyaningrum, Upaya Peningkatan Kemampuan ...

berbasis android terdiri dari 4 langkah, yaitu (1) orientasi (2) kerja kelompok, (3) tes/kuis serta 4) penghargaan kelompok.

Analisis data hasil penelitian yang berupa lembar tes kemampuan berpikir kreatif menggunakan indikator yang diadaptasi dari Silver (dalam Siswono, 2007) yang meliputi (1) Kefasihan (fluency), (2) Fleksibilitas (flexibility), dan (3) Kebaruan (novelty).

Data kemampuan berpikir kreatif mahasiswa dianalisis untuk setiap indikator dengan menggunakan skor gain ternormalisasi $\langle\mathrm{g}\rangle$. Skor gain ternormalisasi merupakan perbandingan skor gain aktual dengan skor gain maksimal. Skor gain actual merupakan skor gain yang diperoleh oleh mahasiswa, sedangkan skor gain maksimal merupakan skor gain tertinggi yang mungkin diperoleh mahasiswa. Rumus dari skor gain ternormalisasi sebagai berikut.

$$
<g>=\frac{T_{1}^{\prime}-T_{1}}{T_{\text {maks }}-T_{1}}
$$

Keterangan:

$\langle\mathrm{g}\rangle$ : skor gain ternormalisasi

$\mathrm{T}_{1}$ ' : skor posttest

$\mathrm{T}_{1}$ : skor pretest

Pembelajaran yang baik jika skor gain ternormalisasi lebih dari 0,4.

Menurut Hake (2007), skor gain ternormalisasi terbagi menjadi tiga kategori yang dapat dilihat pada Tabel 2.

Tabel 2. Kriteria Skor Gain Ternormalisasi

\begin{tabular}{|l|l|}
\hline $\begin{array}{c}\text { Skor gain } \\
\text { ternormalisasi }\end{array}$ & Klasifikasi \\
\hline $0,00<\mathrm{h} \leq 0,30$ & Rendah \\
\hline $0,30<\mathrm{h} \leq 0,70$ & Sedang \\
\hline $0,70<\mathrm{h} \leq 1,00$ & Tinggi \\
\hline
\end{tabular}

\section{HASIL}

Penelitian ini memberikan hasil data kemampuan berpikir kreatif yang berupa (1) Kefasihan (fluency), (2) Fleksibilitas (flexibility), dan (3) Kebaruan (novelty). Secara keseluruhan hasil kemampuan awal berpikir kritis kepada 47 mahasiswa dapat dilihat sebagai berikut. 
Winata, Cacik. Sulistyaningrum, Upaya Peningkatan Kemampuan ...

Tabel 3. Hasil Pretest Kemampuan Beripir Kreatif Mahasiswa

\begin{tabular}{|l|c|}
\hline \multicolumn{1}{|c|}{ Aspek Penaliaian } & $\begin{array}{c}\text { Skor pretest rata-rata } \\
\text { yang diperoleh }\end{array}$ \\
\hline Kefasihan & 2,85 \\
\hline Fleksibilitas & 1,71 \\
\hline Kebaharuan & 1,04 \\
\hline
\end{tabular}

Tabel 4. Hasil Posttest Kemampuan Beripir Kreatif Mahasiswa

\begin{tabular}{|l|c|}
\hline \multicolumn{1}{|c|}{ Aspek Penaliaian } & $\begin{array}{c}\text { Skor posttest rata-rata } \\
\text { yang diperoleh }\end{array}$ \\
\hline Kefasihan & 3,14 \\
\hline Fleksibilitas & 3,02 \\
\hline Kebaharuan & 3,35 \\
\hline
\end{tabular}

Tabel 5. Hasil Analisis Skor Gain Ternormalisasi Kemampuan Beripir Kreatif Mahasiswa

\begin{tabular}{|l|c|c|}
\hline \multicolumn{1}{|c|}{ Aspek Penilaian } & $\begin{array}{c}\text { Skor gain } \\
\text { ternormalisasi }\end{array}$ & Klasifikasi \\
\hline Kefasihan & 0,50 & Sedang \\
\hline Fleksibilitas & 0,57 & Sedang \\
\hline Kebaharuan & 0,77 & Tinggi \\
\hline
\end{tabular}

\section{PEMBAHASAN}

Indikator berpikir kreatif ada tiga yaitu kefasihan, fleksibilitas, dan kebaruan. Kemampuan berpikir kreatif pretest menunjukkan bahwa ketiga indikator memiliki ratarata skor sebesar $<3$. Sedangkan kemampuan berpikir kreatif posttest menunjukkan bahwa ketiga indikator memiliki rata-rata skor sebesar $>3$. Berdasarkan perolehan pretest dan posttest yang selanjutnya dinalisis dengan skor gain ternormalisasi maka indikator kebaharuan menunjukkan hasil yang paling tinggi dibandingkan dengan hasil indikator kefasihan dan fleksibilitas. Jika diklasifikasikan indikator kebaharuan termasuk dalam klasifikasi yang tinggi. Selain itu, indikator kefasihan dan fleksibilitas menunjukkan hasil klasifikasi sedang.

Hasil pretest kemampuan berpikir kreatif dengan indikator kefasihan diperoleh skor rata-rata yaitu 2,85, sedangkan hasil posttest kemampuan berpikir dengan indikator kefasihan diperoleh skor rata-rata yaitu 3,14. Berdasarkan hasil pretest mahasiswa yang masih rendah tersebut ditandai dengan mahasiswa yang masih kurang mampu dalam 
Winata, Cacik. Sulistyaningrum, Upaya Peningkatan Kemampuan ... menjawab dan memberikan ide yang beragam. Selain itu penyebab mahasiswa kemampuan kefasihan rendah karena mahasiswa belum mampu dalam mengungkapkan gagasan dengan cepat. Melalui pembelajaran kooperatif berbasis android memberikan hasil postest yang meningkat, terlihat dari hasil analisis skor gain ternormalisasi yang termasuk dalam klasifikasi sedang. Pada pembelajaran kooperatif melatih mahasiswa secara kolaboratif saling memberikan ide secara berkelompok sehingga mahasiswa terlatih untuk menungkapkan ide yang dimilikinya pada orang lain. Selain itu adanya peran android yang dilengkapi dengan fitur-fitur permasalahan kontekstual pada tahap orientasi dalam pembelajaran kooperatif. Hasil ini sejalan dengan pendapat Heryati (2019), menyatakan bahwa model pembelajaran kooperatif menekankan pada partisipasi dan aktivitas keterlibatan individu dalam kelompok.

Indikator fleksibilitas masih rendah pada hasil pretest yang ditunjukkan dengan perolehan skor rata-rata 1,71. Hasil ini terlihat dari masih rendahnya pemahaman permasalahan dan solusi dalam memperkirakan secara otomatis rencana penyelesaian masalah, serta melihat kembali jika terjadi hambatan dalam memperoleh solusi. Setelah dilakukan treatment dengan pembelajaran kooperatif berbasis android maka hasil indikator fleksibilitas saat posttest menjadi 3,02. Hasil analisis skor gain ternormalisasi menunjukkan hasil klasifikasi sedang. Melalui pembelajaran kooperatif maka mahasiswa mampu menghasilkan gagasan, jawaban, dan pertanyaan yang bervariasi saat kegiatan kerja dalam kelompok. Selain itu, mahasiswa dapat melihat suatu masalah dari sudut pandang yang berbeda-beda, mencari banyak alternative atau arah yang berbeda-beda dan mampu mengubah cara pendekatan atau pemikiran dalam aktifitas pembelajaran kooperatif. Hasil penelitian ini sejalan dengan hasil penelitian dari Siswono (2008) yang menyebutkan bahwa kemampuan berpikir kreatif seseorang semakin tinggi, jika seseorang tersebut mampu menunjukkan banyak kemungkinan jawaban pada suatu masalah.

Indikator terakhir yaitu kebaharuan. Pada indikator ini, hasil pretest menunjukkan rata-rata skor sebesar 1,04, dan termasuk terkecil dalam perolehan pretest. Berdasarkan hasil indikator kebaharuan yang masih rendah tersebut maka mahasiswa masih belum dapat menyelesaikan permasalahan dan cenderung didasarkan pada pengalaman. Sebagian besar mahasiswa tidak mengubungkan kebaharuan dengan kemajuan teknologi sehingga dibutuhkan pembelajaran berbasis teknologi untuk 
Winata, Cacik. Sulistyaningrum, Upaya Peningkatan Kemampuan ...

meningkatkan kreatifitas dengan menyesuaikan kondisi sekarang. Setelah dilakukan treatment dengan pembelajaran kooperatif berbasis android maka hasil indikator kebaharuan saat posttest menjadi 3,35. Hasil analisis skor gain ternormalisasi menunjukkan hasil klasifikasi tinggi dan termasuk tertinggi dibandingkan dua indikator yang lain. Indikator kebaharuan memberikan hasil klasifikasi tinggi dalam penerapan pembelajran kooperatif berbasis android. Hal ini disebabkan oleh pembelajaran kooperatif yang membangun pemahaman konsep serta penerapannya dalam kehidupan nyata. Selain itu, pemebalajaran kooperatif berbasis android dapat menghubungkaan pengetahuan yang sudah mereka peroleh dengan pengetahuan baru yang selalu diupdate dengan fitur-fitur sumber belajar dan materi yang ada di android.

Berdasarkan hasil dari ketiga indikator tersebut maka pembelajaran kooperatif berbasis android memberikan dampak positif dalam upaya peningkatan kemampuan berpikir kritis.

\section{SIMPULAN}

Berdasarkan hasil penelitian dan pembahasan maka dapat disimpulkan bahwa (1) hasil pretest indikator kefasihan, fleksibelitas, dan kebaharuan berturut-turut adalah 2,85; 1.71; dan 1,04. (2) hasil posttest indikator kefasihan, fleksibelitas, dan kebaharuan berturut-turut adalah 3,14; 3,02; dan3,35. (3) Kemampuan berpikir kreatif mahasiswa dapat mengalami peningkatan pada ketiga indikator melalui pembelajaran kooperatif berbasis android. Indikator kefasihan dan fleksibelitas memperoleh hasil sedang dengan hasil secara berturut-turut yaitu 0,50 dan 0,54 . Indikator kebaharuan memberikan hasil tertinggi yaitu 0,78 .

\section{DAFTAR RUJUKAN}

Azhari dan Somakim. 2013. Peningkatan Kemampuan Berpikir Kreatif Matematik Siswa Melalui Pendekatan Konstruktivisme di Kelas VII Sekolah Menengah Pertama (SMP) Negeri 2 Banyuasin III, Jurnal Pendidikan Matematika, 7(2): 112.

Coughlan A. 2007. LEARNING TO LEARN: Creative Thinking and Critical Thinking.DCU Students Learning Resources. (Online). (http://www.dcu.ie/ovpli/Student_Learning_Resources/design/PdfFiles/1DWhati screativeandcriticalthink ing.pdf), Accesed on $3^{\text {rd }}$ Maret 2016.

Durkheim, E. 1982. The Rules Of Sociological Method. New York: The Free Press. 
Winata, Cacik. Sulistyaningrum, Upaya Peningkatan Kemampuan ...

Florebtina, N., \& Leonard. 2017. Pengaruh Model Pembelajaran Kooperatif Terhadap Kemampuan Berpikir Kreatif Matematis Siswa, Jurnal Formatif, 7(2): 96-106.

Hake, R.R. 2007. Design-Based Research in Physics Education Research: A Review. (Online). (http://www. physics.indiana.edu/ hake/DBRPhysics3.pdf), ,Accesed on $17^{\text {th }}$ Desember 2013.

Heryati, T. 2019. Meningkatkan Kemampuan Berpikir Kreatif Peserta Didik dengan Model Pembelajaran Kooperatif Tipe Investigasi Kelompok, Jurnal Edukasi, 7(2): 69-90.

Kim, K. H. 2006. Can We Trust Creativity Test? A Review of the Torrance Tests of Creative Thinking (TTCT), Creativity Research Journal, 18(1): 3-14.

Mahmudi, A. 2011. Pengaruh Strategi MHM Berbasis Masalah terhadap Kemampuan Berpikir Kreatif Matematis dan Persepsi Terhadap Kreativitas. Yogyakarta: FMIPA UNY. Makalah ini termuat pada Jurnal Cakrawala Pendidikan Lembaga Pengabdian Masyarakat Universitas Negeri Yogyakarta Tahun 2011.

Mardiana, N. 2017. Peningkatan Physics Hots Melalui Mobile Learning (Mobile Learning to Improve Physics Hots), Journal PASCAL (Journal of Physics and Science Learning), 1(2): 1-9.

Muslich, Masnur. 2009. Melaksanakan PTK Itu Mudah (Clasroom Action Research) Pedoman Praktis bagi Guru Profesional. Jakarta: Bumi Aksara.

National Research Council (NRC). 1996. National Science Education Standarts. Washington: National Academy Press.

Siswono, T. Y. E. 2006. Desain Tugas untuk Mengidentifikasi Kemampuan Berpikir Kreatif Siswa dalam Matematika, Jurnal Pancaran Pendidikan, 19(63): 495509.

Siswono, T. Y. E. 2008. Model Pembelajaran Matematika Berbasis Pengajuan dan Pemecahan Masalah Untuk Meningkatkan Kemampuan Berpikir Kreatif. Surabaya: Unesa University Press.

Sulistyaningrum, H., Winata, A., \& Cacik, S. 2019. Analisis Kemampuan Awal 21st Century Skills Mahasiswa Calon Guru SD, Jurnal Pendidikan Dasar Nusantara, 5 (1), 142-158.

Suryadi, D., \& Herman, T. 2008. Eksplorasi Matematika Pembelajaran Pemecahan Masalah. Jakarta: Karya Duta Wahana.

Sultoni, A., \& Agoestanto, N. 2016. Upaya Peningkatan Kemampuan Berpikir Kreatif dengan Problem Based Learning Berpendekatan Scientific pada Materi Trigonometri, diseminarkan di Seminar Nasional Matematika yang diselengarakan oleh FMIPA UNES pada 1 Februari 2016.

Sykes, E. R. 2014 . New Methods of Mobile Computing: From Smartphone to Smart Education, Tech Trends, 26-37. 